\title{
Overlay removable partial denture as temporary restoration of vertical dimension of occlusion in a bruxist patient
}

\author{
Overlay removivel como tratamento provisório para restabelecimento da dimensão vertical de oclusão de \\ paciente bruxista
}

Fernanda Maria CESTO'

Lorena DOMARESKI ${ }^{1}$

Adriana Postiglione Bührer SAMRA ${ }^{1}$

Karin Hermana NEPPELENBROEK²

Nara Hellen CAMPANHA'

Vanessa Migliorini URBAN ${ }^{1}$

\begin{abstract}
The reestablishment of the vertical dimension of occlusion is an important phase during prosthodontics treatment. Its reduction can be a consequence of severe bruxism, and patient rehabilitation requires complex, expensive, and long treatments. In this context, an overlay removable partial denture is a viable alternative, as it represents a simple manufactured reversible treatment. As a temporary treatment, it does not require tooth wear, reestablishes vertical dimension of occlusion, and allows the patient to adapt to this new dimension until the definitive rehabilitation treatment can be planned and finished. This case report describes the temporary rehabilitation of a maxillary complete edentulous bruxist patient with excessive tooth wear on his lower jaw, seeking treatment at the Removable Prosthodontics Department at State University of Ponta Grossa to replace his upper complete denture. A new complete denture was made and the implementation of an overlay removable partial denture was proposed to be made to the lower arch, which provided aesthetics and function to the patient until the completion of the definitive work. The patient was instructed and guided about the causal factors and consequences of his parafunctional habit and was taught methods for self-perception to control frequency. For the final rehabilitation, a new maxillary complete denture with metal occlusal surfaces will be made as well as metaloceramic crowns with metal occlusal using intraradicular retention with cast posts. An occlusal splint will be inserted in the lower jaw as supportive therapy to control the parafunctional habit.
\end{abstract}

Indexing terms: Bruxism. Denture overlay. Temporary dental restoration. Vertical dimension.

\section{RESUMO}

O restabelecimento da dimensão vertical de oclusão é uma etapa importante e indispensável durante a realização de trabalhos protéticos. Sua diminuição pode ser consequência do bruxismo severo e a reabilitação dos pacientes exige a realização de tratamentos complexos, de alto custo e tempo prolongado para execução. Neste contexto, a prótese parcial removível overlay é uma alternativa viável, pela reversibilidade do tratamento e simplicidade de execução. Como tratamento provisório, não necessita de preparo dental, restabelece a dimensão vertical de oclusão e permite que o paciente se adapte a esta nova dimensão, até que seja planejado e executado o tratamento reabilitador definitivo. O presente caso clínico descreve a reabilitação provisória de um paciente bruxista, desdentado total superior, com desgaste dental excessivo na arcada inferior que procurou tratamento na Clínica de Prótese Removível da Universidade Estadual de Ponta Grossa para substituição de sua prótese total superior. Uma nova prótese total foi confeccionada e proposta a execução de uma prótese parcial removível overlay para o arco inferior, a qual devolveu estética e função ao paciente até a realização do trabalho definitivo. O paciente foi instruído e orientado sobre os fatores desencadeantes e consequências de seu hábito parafuncional e conscientizado no intuito da autopercepção para controle da frequência. Para a reabilitação final, será confeccionada uma nova prótese total superior com superfícies oclusais metálicas, coroas metalocerâmicas com oclusal em metal utilizando retenção intracanal com núcleos metálicos fundidos. Uma placa miorrelaxante será instalada sobre a arcada inferior como terapia de suporte para controle do hábito parafuncional.

Termos de indexação: Bruxismo. Revestimento de dentadura. Restauração dentária temporária. Dimensão vertical.

\footnotetext{
${ }^{1}$ Universidade Estadual de Ponta Grossa, Departamento de Odontologia. Av. General Carlos Cavalcanti, 4748, 84030-900, Campus de Uvaranas, Ponta Grossa, PR, Brasil. Correspondência para / Correspondence to: VM URBAN. E-mail: <vanurban@yahoo.com>

${ }^{2}$ Universidade de São Paulo, Faculdade de Odontologia, Departamento de Prótese. Bauru, SP, Brasil.
} 


\section{INTRODUCTION}

The vertical dimension of occlusion (VDO) can be defined as the vertical distance between the maxilla and the mandible when the teeth are in occlusion. It is an important factor to be identified on clinical examination and should not be underestimated at the beginning of any prosthodontic restorative treatment ${ }^{1}$.

Excessive decreases in VDO may be due to intense bruxism², characterized by nonfunctional contact of teeth by grinding or clenching them. This habit can be daytime and/or nightly, voluntary or involuntary, and it is multifactorial, involving local, systemic, psychological, and behavioral factors ${ }^{3}$. In addition, it is considered an important etiologic factor of temporomandibular disorders and can be one of the main causative factors in the failure of restorative dentistry4.

A decreased VDO does not cause significant discomfort because it does not interfere with muscle length but rather alters the mandibular opening and closing, changing the direct relationship between the anterior guide teeth ${ }^{5}$. The loss of VD may have some characteristics such as reduction of the lower face and, thus, a facial disharmony, increased functional free space, and angular cheilitis ${ }^{6}$.

The rehabilitation of partially edentulous patients requiring restoration of vertical dimension and/or realignment of the occlusal plane may involve complex, time-consuming, and high-cost treatments ${ }^{7}$. In some cases, practitioners perform the rehabilitation by the random replacement of missing teeth, resulting over time in harmful disorders to the stomatognatic system. The overlay removable partial denture (RPD) is a viable alternative for these cases, with financial and biological advantages, reversibility, and simplicity of treatment ${ }^{7}$.

This type of rehabilitation can be defined as an atypical RPD, which covers the occlusal surfaces of the pillar teeth without additional preparation to support the prosthesis in order to restore the occlusal surfaces of the teeth and the chewing ${ }^{2}$. It is worth mentioning the importance of this prosthesis as an aid in making the diagnosis and prognosis and planning the final oral rehabilitation treatment in patients with severely worn teeth and reduced VDO, allowing the evaluation of aesthetics, function, and patient acceptance, prior to implementing permanent changes in natural dentition ${ }^{8}$.

Within this context, a clinical case using this rehabilitative therapy is presented in order to detail its planning and execution and discuss the advantages and indications, aiming to expand its use in clinical practice. Moreover, the proposal for the final rehabilitation of the patient with respect to the longevity of the treatment, aesthetics, and function will be presented and discussed.

\section{CASE REPORT}

Patient A.T., a 48-year-old man, sought treatment at the Removable Denture Clinic of the State University of Ponta Grossa for replacement of the upper denture, which presented wear on the artificial teeth and a fracture in the tuberosity region. In the lower arch the presence of a RPD replacing two dental elements (lost 13 years ago due to an accident with fireworks) was observed. This prosthesis was unadapted and unsatisfactory (Figure 1).

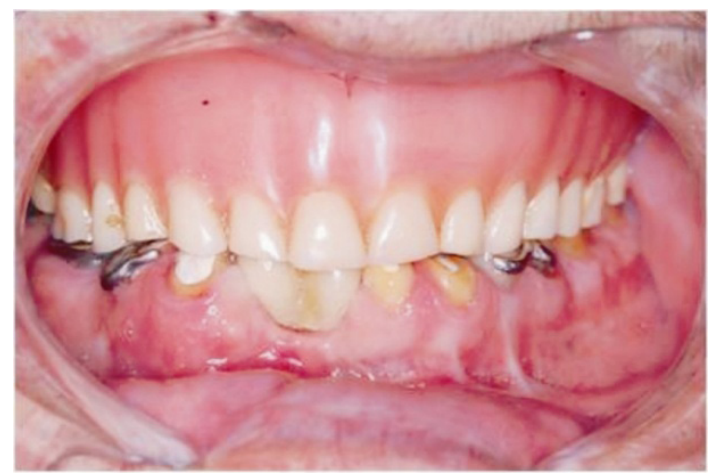

Figure 1. Initial clinical case.

During the anamnesis, the continued use of the following systemic medications was reported: Brasart ${ }^{\circledR}$ (valsartan) $320 \mathrm{mg}$ and Amlodil ${ }^{\circledR}$ (amlodipine besylate) $5 \mathrm{mg}$ for the treatment of hypertension; Dormec ${ }^{\circledR}$ (acetylsalicylic acid) $100 \mathrm{mg}$ to improve blood circulation; Metformin hydrochloride $850 \mathrm{mg}$ as a hypoglycemic agent; and Simvastatin $10 \mathrm{mg}$ for reducing elevated cholesterol levels. The patient claimed to have fibromyalgia but did not use medication for treatment.

Due to the patient's reported pain in the facial muscles upon awakening, a questionnaire on temporomandibular disorders and orofacial pain was administered. This pain was relieved with the use of warm compresses. The pain resulting from tooth sensitivity was described as irradiated, sharp, intensity 10 (analog scale of 0 to 10), aggravated by the ingestion of cold liquids or food, and started when the teeth began to suffer from wear. Restrictions of mandibular movements or joint noises were not observed. The patient did not report pre- or intra-articular sensitivity or pain during 
functional movements and had never sought treatment for temporomandibular disorders.

During an intraoral clinical examination, excessive wear was observed on the remaining lower teeth at approximately the middle and cervical third (Figure 2A). The lower arch was partially edentulous, with absence of teeth $31,41,42$, and 45 . The upper teeth, missing due to caries, were lost 30 years ago when the first denture was installed. Since that time, the patient had had six dentures, which were also currently unused due to fracture or mismatch. Complementary tests were performed, as panoramic, occlusal, and periapical radiographs of the remaining teeth, which showed good periodontal attachment.

Due to the excessive wear of the teeth and dentures without restoration of the occlusal plane, the VDO was reduced. This played a major role in the decision for the overlay RPD option, aiming to restore the VDO and using it to aid in the diagnosis and planning of the final prosthetic rehabilitation.

Sequentially, the conventional clinical steps were undertaken for making a new, superior, complete denture by preliminary impression with alginate (Jeltrate Plus, Dentsply, Rio de Janeiro, Brazil), functional impression by the selective pressure technique with low-fusion impression compound sticks (Exact, DFL, Rio de Janeiro, Brazil) and zinc-oxide eugenol impression paste (Technew, Rio de Janeiro, Brazil), and determining the occlusal plans based on aesthetic aspects for mounting of artificial teeth. The reinforced artificial teeth (Trilux ${ }^{\circledR}, \mathrm{VIPI}$, Pirassununga, Brazil) were mounted on wax and proven in the patient, who approved and authorized the processing of the interim complete denture.

After installing the new, superior, complete denture, the procedures for making the lower acrylic overlay RPD were carried out. First, a preliminary impression was made with an irreversible hydrocolloid (Jeltrate Plus, Dentsply, Rio de Janeiro, Brazil) and pouring of the corresponding model with stone type IV (Durone, Dentsply, Rio de Janeiro, Brazil) (Figure 2B). In this model, an appliance of acrylic resin and wax in the anterior toothless region was created to help determine the VDO and register the intermaxillary relations.
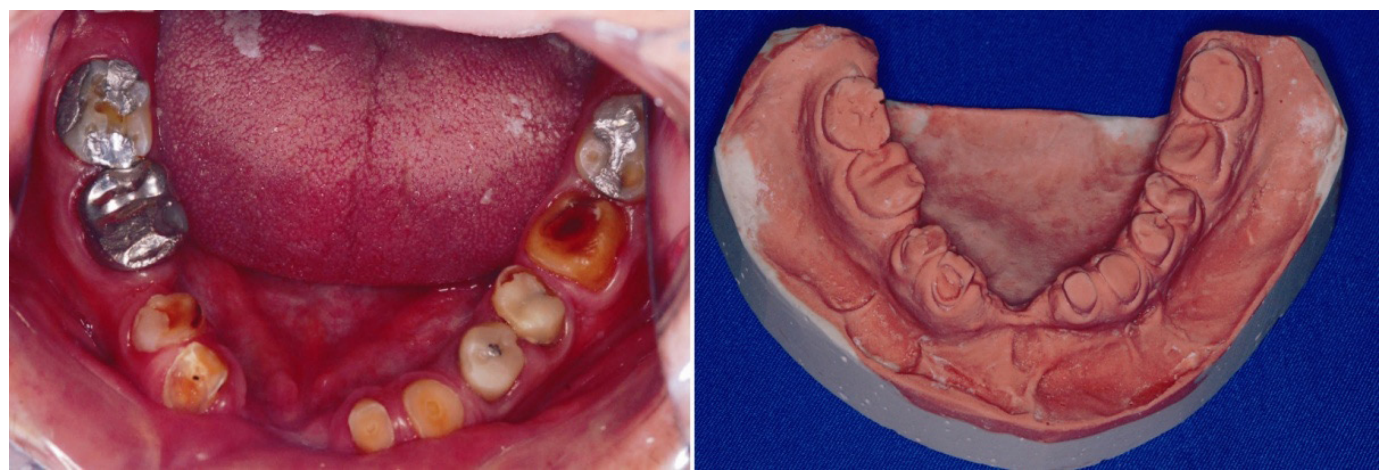

Figure 2. A) Remaining lower teeth with excessive wear; B) Preliminary model in stone type IV.

To determine the VDO, the association of metric Pleasure's ${ }^{9}$ and aesthetic Turner and Fox ${ }^{10}$ methods were used. The patient was comfortably seated in an upright position with the head resting on the chair and was told to remove the superior complete denture. Two median points were marked on the face of the patient, one on his chin and the other on his nose, and the patient was asked to moisten his lips, swallow, and pronounce repeatedly the letter " $M, M, M$ " for 5 minutes. At the end of this period, the jaw is directed toward the muscle-relaxing position, with a parameter used to determine the rest vertical dimension. The distance between the two points was measured using a compass, and an average value was obtained. Next, three $\mathrm{mm}$ were deducted from this amount corresponding to the freeway space or pronunciation, obtaining the VDO ${ }^{11}$. The height of the lower denture base plate was adjusted, removing the wax until, in contact with the antagonist prosthesis, the distance between the points marked on the face of the patient was at the VDO previously determined ${ }^{11}$. Subsequently, subjectively facial harmony of the patient was found by comparing the tone of your facial muscles with the lips for a conference if the VDO initially determined was adequate ${ }^{11}$. The Willis compass was then used to record the value of the VDO $(69 \mathrm{~mm})$. 
The centric relation $(C R)$ was recorded from the association of the methods of tongue retraction ${ }^{12}$, in which the patient was asked to place the tip of his tongue on the palate as far back as possible; swallowing ${ }^{13}$, in which he was asked to swallow and close the mouth slowly; and guided not forced, while maintaining the methods mentioned above, the patient's jaw was guided gently with the operator hand on his chin during the closing movement. The lower denture base plate was stabilized with the thumb and index fingers of one hand and, with the same fingers of the other hand, his jaw was guided ${ }^{11}$.

After determining the RC position, an interocclusal record was made using heavy condensation silicone (Profile, Vigodent, Rio de Janeiro, Brazil), between the superior complete denture and the lower teeth, based on the determined value for the VDO (Figure 3). The casts were mounted in a semi-adjustable articulator (SAA) using the obtained record. The incisal guide pin was placed and kept at zero; the articulator was placed upside-down; the set of base plate and interocclusal record in silicone was inserted on the lower cast and these were embedded in the antagonist cast (duplicated complete denture) that was already mounted in SAA from taking the face-bow. Stone type IV (Durone, Dentsply, Rio de Janeiro, Brazil) was manipulated and poured on the basis of the lower cast. The lower member of the articulator was placed in position until it was touched by the incisal pin. Initially, a pillar with stone type IV was made, the setting was awaited, and then the mounting was completed using model plaster for filling ${ }^{11}$. The articulator was sent to the laboratory for waxing (Figure 4) and processing the overlay prosthesis, recovering the lost VDO of the patient.

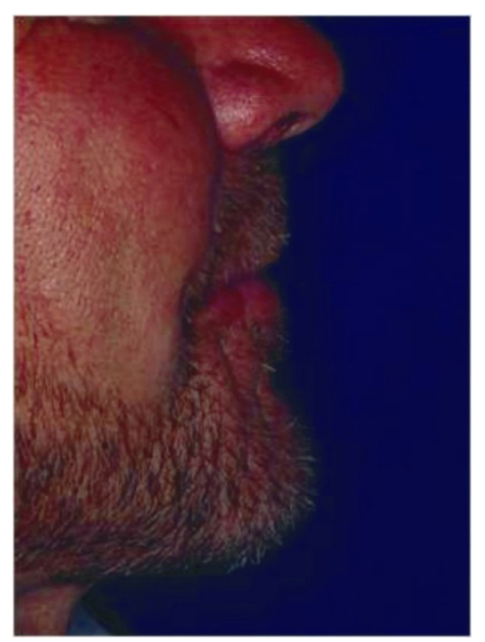

Figure 3. Profile of the patient after restoration of VDO.

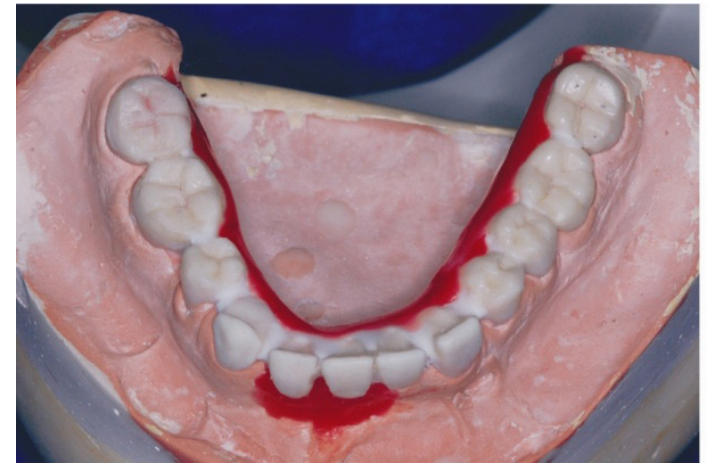

Figure 4. Waxing of overlay RPD.

The patient returned for installation and occlusal adjustments of the overlay RPD (Figure 5); and the prosthesis was approved by him (Figure 6).

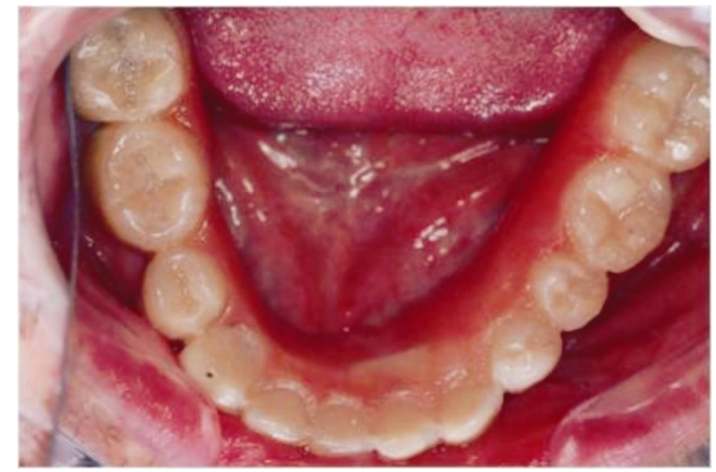

Figure 5. Overlay RPD in the patient.

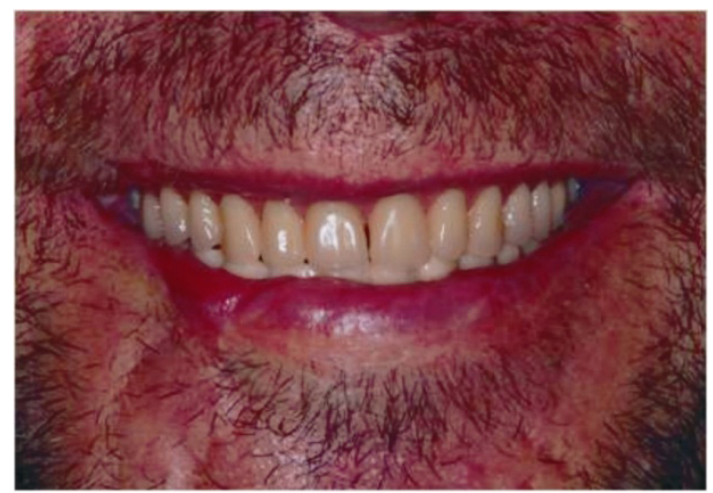

Figure 6. Final smile of the patient.

After six months of adaptation to the new VDO, the patient will be rehabilitated with a new upper complete denture with a metal occlusal surface and metal ceramic crowns with metal occlusal surfaces using intracanal retention with cast metal post in the lower arch. The patient will be sent to the Temporomandibular Clinic at the State University of Ponta Grossa, and an occlusal splint will be installed on the lower arch as supportive 
therapy for control of parafunctional habit. Importantly, the provisional restorative option was presented and detailed to the patient, who signed a consent form at the beginning of treatment.

\section{DISCUSSION}

It has been reported that during parafunctional activity, a force of approximately six times higher than that generated during physiological mandibular motion is applied on the occlusal surface of teeth ${ }^{14}$. As a result, detrimental effects will be produced at one or more constituent parts of stomatognatic system. Not always, the painful symptom is associated with the main complaint of the patient and the dental wear, resulting in decreased VDO, which is usually the primary alert to the presence of bruxism. Wear facets are observed in incisal surfaces of the anterior teeth, cusps, and restorations on posterior teeth; wear pattern is non-uniform and results in excessive reduction of the clinical crown height. Enamel cracks, cervical erosions, crown fractures, tooth sensitivity, and changes in intermaxilar relationship ${ }^{4,14}$ also can be observed. Bruxism presented by the patient was classified as occurring nightly with pain in the muscles of the face to until waking up, as well as in the daytime, since the patient said he noticed gritting his teeth at certain times of day. Despite this, restriction or pain during jaw movements, noises, and sensitivities in the temporomandibular joint region were not observed.

Despite the obvious and excessive wear of the lower teeth, the patient had sought dental treatment only for replacing his old superior complete denture. The patient had a lower partial denture that did not meet the biomechanical principles and was not aesthetic or able to rehabilitate the lower third of the face. After the presentation of the interim solution for handling of the case and approval by the patient, the lower overlay RPD was made and installed. The patient was very pleased with the result and said, "It seems they are my teeth. I could take this one." Thus, the patient gained confidence and motivation to carry out the definitive treatment.

The overlay RPD covers the occlusal/incisal surface of the teeth in order to restore the reduced VDO, return an appropriate maxillomandibular relationship, and recovering the aesthetics, facial harmony, and efficient chewing function; and it is a reversible and temporary treatment ${ }^{7}$. In addition, according to De Freitas et al. ${ }^{15}$, this therapy allows the patient to choose another treatment when the overlay no longer meets a patient's needs, due to its easy reversibility. This prosthesis has also been called occlusal coverage RPD, onlay RPD, or support onlay?.

In general, the overlay RPDs may be named according to their structure and the material employed in the occlusal coating. They can be metallic, acrylic ${ }^{8}$, porcelain, or mixed with metal projections and aesthetic ${ }^{16}$ coating. According to its function, they can be classified as temporary ${ }^{8}$, definitive ${ }^{2}$, or therapy when used only in the period necessary for the remission of symptoms.

This specific type of prosthesis has the following indications: restoration of the occlusal plane when applied to premolars and molars; pretreatment to orthognathic surgery with the purpose of occlusal stabilization and muscle conditioning; restoration of VDO, and as a guide for oral rehabilitation ${ }^{17}$. Furthermore, it was considered particularly applicable in cases of open bite and restoration of a correct occlusal plane by poor mandibular position when more extensive treatment modalities are contraindicated ${ }^{16}$, and it can also be used as an efficient solution for the treatment of patients with congenital and acquired defects or as transient or interim prosthesis ${ }^{18}$.

Some advantages of the overlay RPD include: restoration of aesthetics and function with enamel maintenance; reduced operating time (resulting in less stress for the patient); financial economics; psychological gain and reintegration of patients to social life; reversibility when compared to conventional fixed prostheses and orthodontic treatment; ease of cleaning due to its supragingival margins; lower complexity for repairs; better transmission of forces through the occlusal coverage; and efficient restoration of maxillomandibular relationship, occlusal stability, muscular condition, condylar position, and extent of jaw movements ${ }^{16-17}$. However, certain disadvantages have been mentioned, such as: complexity of laboratory technique; difficulty adjusting to both the structure and the occlusion; as well as discomfort and temporary phonetic difficulty due to the weight and volume of prosthesis ${ }^{15}$.

It is worth mentioning the importance of the overlay RPD as an aid in diagnosis, prognosis, and planning the final oral rehabilitation treatment in patients with severely worn teeth and reduced VDO, allowing the evaluation of aesthetics and function and ensuring that the pre-established VDO provide comfort to patients ${ }^{15}$ prior to implementing permanent changes in natural dentition ${ }^{8}$. According to Dahl ${ }^{19}$, a period of adaptation post-VDO restoration is necessary, since errors in this step can cause further damage to the patient. Dekon et al. ${ }^{14}$ mentioned that assessing the VDO accuracy should happen forty days 
or more after the provisional treatment was instituted, during which the patient should report the absence of symptoms and accommodation to the new VDO, and then the final rehabilitation treatment can be realized.

The final restorative option proposed for the case and approved by the patient was metal-ceramic crowns with metal occlusal in the lower arch associated with intraradicular retention with cast posts in teeth $36,35,34,33,32,43$, 44 , and 46 . Because teeth 37 and 47 have a slightly larger amount of tooth remaining, they need no intracanal retention and receive total metal crowns due to reduced posterior interocclusal space. The superior complete denture will be duplicated using the technique of therapeutic cloning ${ }^{20}$, and posterior teeth will present metal occlusal surfaces according to the protocol proposed by Lloyd ${ }^{21}$.

Depending on the clinical situation, a core can be enough to offer retention to tooth crown; but the considerable loss of tooth structure, as in the case presented, prevents this procedure. Cast posts are undoubtedly the most traditionally used in the teeth-restoration process with extensive coronal destruction and previous endodontic treatment. Furthermore, these attachments are indicated in cases of extensive rehabilitation, tooth realignment, and in elliptical or excessively conic root canals ${ }^{22}$. The great loss of remaining tooth structure coupled with the fact that an extensive rehabilitation guarantee the indication of such retention to the case presented.

Therapeutic cloning technique is considered to be simplified because it "parts of existing information, obtained through the prosthesis that the patient is using"20. In this method, through good planning, weaknesses of the old prosthesis are corrected keeping the good points, assuming that the previous prosthesis is close to optimal. Once the superior complete denture has been made, following the principles of maximum extension of denture-bearing area, selective pressure, aesthetics, comfort, and restoration of VDO and occlusion plans, it was considered an appropriate starting point for his cloning for final rehabilitation.

The selection of artificial teeth for complete denture is of paramount importance during the rehabilitation for providing normal conditions and neuromuscular balance ${ }^{23}$. Thus, they should possess important properties such as wear resistance and ability to maintain a stable occlusal relationship ${ }^{24}$, as well as to absorb some energy during function ${ }^{25}$. Furthermore, the antagonist coating occlusal surface material should be considered during the selection. Probably, the major disadvantage of the acrylic resin artificial tooth is the rapid wear of the occlusal posterior teeth. In order to improve this, acrylic resin artificial teeth with superior mechanical properties have been developed using increased molecular weight, interpenetrating polymer net (IPN teeth) ${ }^{26}$, copolymers ${ }^{27}$, and mineral ${ }^{28}$. In addition, composite resin artificial teeth were introduced around 1980 to improve this disadvantage ${ }^{29}$. According to manufacturers, all these artificial teeth have a higher abrasion resistance than those based on conventional acrylic resin ${ }^{23}$ allowing use in patients with higher masticatory efficiency and subjection to greater tooth wear, especially in cases of implant supported complete dentures and monomaxillar prostheses ${ }^{23}$.

Due to the presence of parafunctional habits in this clinical case, it is believed that only the use of reinforced acrylic teeth in the superior complete denture will not guarantee the maintenance of the VDO. An alternative is to cover the occlusal teeth with metal alloys. According to McGivney \& Castleberry ${ }^{30}$, the metal occlusal coverage may be indicated for various antagonist occlusal surfaces (cast metal restorations, plastic restorations, porcelain, or natural teeth), for patients with bruxism, with reduced interocclusal space, and even with the restoration of occlusal condition in prostheses with acrylic resin artificial teeth (excessive wear or changes in the occlusal relationship as a result of resorption of the alveolar bone edge). Accordingly, there is the possibility of also using metal occlusal surfaces in the lower arch, further favoring the maintenance of the VDO and the possibility of maintaining a stable occlusion for longer.

\section{CONCLUSION}

The overlay removable partial denture provided the patient a temporary alternative that recovered the lost vertical dimension of occlusion. It still permitted an adaptation time to the new dimension, since the execution of definitive treatment requires a long time; returned masticatory function and aesthetics as a guide for implementation of the final work. The patient showed satisfaction with the interim results and became more motivated to definitive treatment. Thus, after examining the case, the overlay removable partial denture can be a rehabilitative option in cases of loss of vertical dimension and severe dental wear.

\section{Collaborators}

FM CESTO, L DOMARESKI, APB SAMRA, NH CAMPANHA, and VM URBAN were responsible for all stages of the clinical case and this writing. KH NEPPELENBROEK contributed to manuscript translation to English before the manuscript was sent to an editing language service provider for grammar revision. 


\section{REFERENCES}

1. Ditterich RG, Romanelli MV, Júnior JAS. Dimensão vertical e relação central em prótese removível: análise e discussão dos métodos de obtenção. Publ UEPG Ci Biol Saúde. 2005;11(3/4):7987.

2. Pavarina AC, Machado AL, Vergani CA, Giampaolo ET. Overlay removable partial dentures for a patient with ectodermal dysplasia: A clinical report. J Prosthet Dent. 2001;86(6):574-7. doi:10.1067/mpr.2001.119981

3. Dias CC, Oliveira SSI, Pires AA. Influência do restabelecimento da dimensão vertical no espaço funcional livre em pacientes com bruxismo. Rev Naval de Odontol on Line. 2007;1(3):5-10.

4. Oliveira GAS, Beatrice LCS, Leão SFS. Reabilitação oral em pacientes com bruxismo: o papel da Odontologia Restauradora. IJD. Int J Dent. 2007;6(4):117-23.

5. Henriques SEF. Reabilitação oral: filosofia, planejamento e oclusão. São Paulo: Santos; 2003.

6. Feltrin PP, Philippi AG, Moretti Junior J, Machado CC, Astolf JA. Dimensões verticais, uma abordagem clínica: revisão de literatura. Rev Odontol Univ Cid Sao Paulo. 2008;20(3):274-9.

7. Souza JEA, Silva ET, Leles CR. Prótese parcial overlay: fundamentos clínicos e relatos de casos. Robrac. 2009;18(47):41-8.

8. Jahangiri L, Jang $S$. Onlay partial denture technique for assessment of adequate occlusal vertical dimension: a clinical report. J Prosthet Dent. 2002;87(1):1-4. doi:10.1067/ mpr.2002.120845

9. Pleasure MA. Correct vertical dimension and freeway space. J Am Dent Assoc. 1951;43(2):160-3.

10. Turrell AJ. Clinical assessment of vertical dimension. 1972. J Prosthet Dent. 2006; 96(2): 79-83. doi:10.1016/j. prosdent.2006.05.015

11. Cartagena AF, Figuerôa RMS, Jorge JH, Urban VM, Bombarda NHC. Montagem de modelos de próteses removíveis em articulador semiajustável. Rev Odontol UNESP. 2012;41(3):21520.

12. Bissasu M. Use of the tongue for recording centric relation for edentulous patients. J Prosthet Dent. 1999;82(3):369-70. doi:10.1016/S0022-3913(99)70097-1

13. Shanahan TE. Physiologic vertical dimension and centric relation. 1956. J Prosthet Dent. 2004; 91(3): 206-9. doi:10.1016/j. prosdent.2003.09.002

14. Dekon SFC, Pellizzeri EP, Zavanelli AC, Ito L, Resende CDA. Reabilitação oral em paciente portador de parafunção severa. Rev Fac Odontol Araçatuba. 2003;24(1):54-9.

15. De Freitas R, Kaizer OB, Pigozo MN, Cavallari P, De Resende DRB. Diagnóstico e tratamento da dimensão vertical de oclusão diminuída. RGO - Rev Gaúch Odontol. 2006;54(2):161-4.

16. Castilho RD, Lamar JRF, Ercoli C. Maxillary and mandibular overlay removable partial dentures for the treatment of posterior open-occlusal relationship: a clinical report. J Prosthet Dent. 2002;87(6):587-92. doi:10.1067/mpr.2002.125578

17. Matsumoto W, Hotta TH, Bataglion C, Rodovalho GV. Tooth wear: use of overlays with metallic structures. J Craniomandibular Pract. $2001 ; 19(1): 61-4$

18. De Sena EF. Sobredentaduras parciales removibles. Acta Odontol Venez. 1998;36(2):107-16.

19. Dahl BL. The face height in adult dentate humans: a discussion of physiological and prosthodontic principles illustrated through a case report. J Oral Rehabil. 1995;22:565-9. doi:10.1111/j.1365-2842.1995.tb01050.x

20. Gomes T, Gomes FL, De Castro Júnior OV. Técnica de clonagem em prótese total. Rev Ibervam Prótese Clín Lab. 2003;5(24):1018.

21. Lloyd PM. Laboratory fabrication of gold occlusal surfaces for removable and implant-supported prostheses. J Prosthodont. 2003;12(1):8-12. doi:10.1053/jopr.2003.8

22. Teófilo LT, Zavanelli RA, Queiroz KV. Retentores intra-radiculares: revisão da literatura. PCL - Rev Ibero-Americana Prótese Clín Lab. 2005;7(36):183-93.

23. Assunção WG, Tabata LF, Nicolau El, Shiwa M, Dos Santos PH. Avaliação in vitro da resistência à abrasão de diferentes dentes artificiais de resina armazenados em saliva artificial. Rev Odontol UNESP. 2006;35(4):285-91

24. Craig RG. Restorative dental materials. 9a ed. St. Louis: Mosby; 1993.

25. Kawano F, Ohguri T, Ichikawa T, Mizuno I, Hasegawa A. Shock absorbability and hardness of commercially available denture teeth. Int J Prosthodont. 2002;15:245-7.

26. Abe $Y$, Sato $Y$, Akagawa $Y$, Ohkawa $S$. An in vitro study of highstrength resin posterior denture tooth wear. Int J Prosthodont. 1997;10(1):28-34

27. Combe EC, Burke FJT, Douglas WH. Polymers. In: Combe EC, Burke FJT, Douglas WH. Dental biomaterials. Boston: Kluwer; 1999. p. 81-92.

28. Hirano S, May KB, Wagner WC, Hacker $\mathrm{CH}$. In vitro wear of resin denture teeth. J Prosthet Dent. 1998;79(2):152-5. doi:10.1016/ S0022-3913(98)70209-4

29. Zeng J, Sato Y, Ohkubo C, Hosoi T. In vitro wear resistance of three types of composite resin denture teeth. J Prosthet Dent. 2005;94:453-7. doi:10.1016/j.prosdent.2005.08.010

30. Mc Givney GP, Castleberry BS. Prótese parcial removível de McCracken. 8a ed. São Paulo: Artes Médicas; 1994.

Received on: 8/2/2012

Final version resubmitted on: 4/8/2012

Approved on: 4/9/2012 
